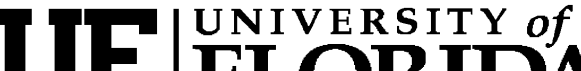 FLORIDA \\ IFAS Extension
}

\section{Nitrogen Fertilization of Strawberry Cultivars: Is Preplant Starter Fertilizer Needed?1}

\author{
Bielinski M. Santos and Alicia J. Whidden²
}

\section{Introduction}

Nitrogen (N) is the most absorbed plant nutrient in per-weight basis of most vegetable crops. This nutrient is an essential component of basic structures in all plant species, and its deficiency can severely affect growth and development. Most of the $\mathrm{N}$ is absorbed through plant roots in the form of the ion nitrate $\left(\mathrm{NO}_{3}\right)$ dissolved in the solution. In soils with low organic matter content, such as the sandy soils throughout Florida, natural N supply is low and supplemental fertilization is required to cover the crop demand of this essential nutrient. In strawberry production, this is achieved in two ways: a) through application during the growing season of all $\mathrm{N}$ through drip lines (fertigation), or b) a combination of this practice and the application of dry preplant starter $\mathrm{N}$ before bed formation.

Recent surveys among strawberry growers in west central Florida showed that about one half of them apply preplant fertilizer formulas that include $\mathrm{N}$. Application rates usually ranged between 20 and 40 lb/acre of N. Environmental concerns over leaching nitrates to Florida ground waters has brought to the forefront the necessity of conducting research on best management practices that could reduce the use of starter fertilizers in production systems where fertigation is available, such as in strawberry fields. Therefore, studies were conducted to determine whether using preplant starter $\mathrm{N}$ fertilization increases strawberry early and total yield.

\section{Response to Starter Fertilizer}

Field studies were conducted during 2005 and 2006 at the Gulf Coast Research and Education Center (GCREC) of the University of Florida, on a Myakka fine sandy soil with $1.2 \%$ of organic matter and $\mathrm{pH}$ 7.2. Planting beds were pre-formed with a standard bedder and were 28 inches wide on the base, 24 inches wide on the top, and 8 inches high. 'Strawberry Festival' bare-root transplants from Canadian nurseries were transplanted in the first week in October of each year.

Plant nutrients other than $\mathrm{N}$ were applied through drip lines according to IFAS recommendations to ensure non-limiting conditions (Peres et al., 2007). Ammonium nitrate was used as the starter fertilizer at a rate of $40 \mathrm{lb} / \mathrm{acre}$ of $\mathrm{N}$. A non-treated control was also included. The fertilizer was broadcast

1. This document is HS1116, one of a series of the Horticultural Sciences Department, Florida Cooperative Extension Service, Institute of Food and Agricultural Sciences, University of Florida. Original publication date August 6, 2007. Visit the EDIS Web Site at http://edis.ifas.ufl.edu.

2. Bielinski M. Santos, assistant professor, Gulf Coast Research and Education Center; Alicia J. Whidden, extension agent, Hillsborough County Extension Service, Cooperative Extension Service, University of Florida, Gainesville, FL 32611.

The Institute of Food and Agricultural Sciences (IFAS) is an Equal Opportunity Institution authorized to provide research, educational information and other services only to individuals and institutions that function with non-discrimination with respect to race, creed, color, religion, age, disability, sex, sexual orientation, marital status, national origin, political opinions or affiliations. U.S. Department of Agriculture, Cooperative Extension Service, University of Florida, IFAS, Florida A. \& M. University Cooperative Extension Program, and Boards of County Commissioners Cooperating. Larry Arrington, Dean 
incorporated 4 inches deep on bed tops before final bed pressing. Afterwards, beds were fumigated and covered with black high-density polyethylene mulch immediately after fumigant injection.

Simultaneously, a single drip line was buried on bed centers. Strawberries were grown following recommended local practices.

The results showed that applying starter $\mathrm{N}$ fertilizer did not improve monthly or total strawberry yield (Figure 1). This indicated that growers can avoid using preplant starter $\mathrm{N}$ fertilizer and still obtain the same yields, provided that appropriate fertigation rates are used to ensure satisfactory crop growth and development.

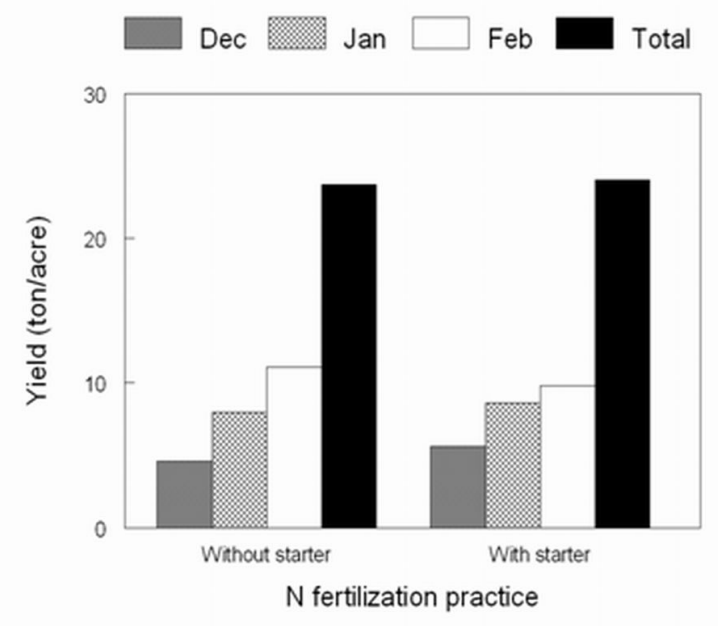

Figure 1. Strawberry marketable yields per month and total in response to the application of starter (preplant) $\mathrm{N}$ fertilizer at a rate of $40 \mathrm{lb} /$ acre.

\section{Literature Cited}

Peres, N.A., J.F. Price, W.M. Stall, C.K. Chandler, S.M. Olson, T.G. Taylor, S.A. Smith, and E.H. Simonne. 2006. Strawberry production in Florida. In: Olson, S.E. and E. Simonne (eds.). Vegetable Production Handbook for Florida, 2005-2006. HS-736, IFAS Extension, Univ. of Florida, pp. 375-382. 